\begin{tabular}{l}
\hline MATAPPA: Jurnal Pengabdian Kepada Masyarakat \\
Volume 1 | Nomor $1 \mid$ Maret | 2018 \\
e-ISSN: 2614-6673 dan p-ISSN: $2615-5273$ \\
\begin{tabular}{|l|l|}
\hline ce) (1) This work is licensed under a Creative Commons Attribution & \\
\hline
\end{tabular}
\end{tabular}

\title{
Sosialisasi Pelaksanaan Konseling Kelompok Pada Guru BK SMA-Ma Kabupaten Bantul
}

\author{
Drajat Edy Kurniawan ${ }^{1)}$ Arum Setiowati ${ }^{2)}$
}

\section{Keywords : \\ Konseling Kelompok}

\section{Corespondensi Author}

Bimbingan dan

Konseling, Universitas

PGRI Yogyakarta

Email: m drajat_cellcius@yahoo.co

\begin{abstract}
ABSTRAK
Tujuan dan target pengabdian ini untuk, 1) Meningkatnya pemahaman guru BK mengenai pelaksanaan layanan konseling kelompok, 2) Meningkatnya kemampuan guru BK dalam memberikan layanan konseling kelompok bagi siswa. Metode yang digunakan untuk mencapai tujuan kegiatan pengabdian dilaksanakan melalui pelatihanPelaksanaan Konseling Kelompok Pada Guru BK SMA/MA Kabupaten Bantul. Pelatihan ini akan dilaksanakan sebanyak 2 kali. Kegiatan pengabdian dilaksanakan pada bulan Februari 2017. Kegiatan pengabdian dilaksanakan melalui beberapa metode pelatihan, yaitu: 1) Metode Ceramah untuk memberikan penjelasan layanan konseling kelompok, 2) Metode Tanya Jawab untuk mengetahui sampai sejauh mana materi layanan konseling kelompoktelah dikuasai, merangsang berpikir dan mempraktekkancara melaksanakan layanan konseling kelompok. Dengan adanya sosialisasi dan pelatihan ini,diharapkan kemampuan guru BK dalam memberikan layanan konseling kelompok dapat meningkat. Dengan meningkatnya kemampuan tersebut maka berimbas pada peningkatan kualitas pemberian layanan pada guru Bimbingan dan Konseling.
\end{abstract}

\section{History Artikel \\ History Artikel \\ Received: $24-02-2018$ \\ Reviewed: 27-02-2018 \\ Revised: $12-03-2018$ \\ Accepted: 20-03-2018 \\ Published: 30-03-2018}

\begin{abstract}
Objectives and targets of this devotion to, 1) Increased understanding of BK teachers on the implementation of group counseling services, 2) Increased ability of GC teachers in providing group counseling services for students. The methods used to achieve the purpose of the devotion activities are carried out through the training of Group Counseling on GC Teachers Bantul District High School. This training will be held 2 times. The devotional activity was conducted in February 2017. The devotional activities were conducted through several training methods, namely: 1) Lecture Method to give explanation of group counseling services, 2) Questioning Methods to find out the extent to which the counseling group care materials have been mastered, stimulated thinking and practicing the way group counseling services. With this socialization and training, it is hoped that the ability of GC teachers to provide group counseling services can increase. With the increase of these capabilities, the impact on improving the quality of service provision in teachers Guidance and Counseling.
\end{abstract}

\section{PENDAHULUAN}

Salah satu upaya yang dilakukan oleh guru bimbingan dan konseling dalam rangka membantu konseli menghadapi masalahnya adalah dengan memberikan pelayanan konseling kelompok. Menurut Prayitno (1997) layanan bimbingan kelompok dan konseling kelompok merupakan dua jenis layanan kegiatan yang saling keterkaitannya sangat besar. Keduanya mempergunakan dinamika kelompok sebagai media kegaitannya. Lebih jauh Sukardi dan Kusmawati (2008) mengungkapkan bahwa 
masalah yang dapat dibahas meliputi berbagai masalah dalam segenap bimbingan (yaitu bidang bimbingan pribadi, sosial, belajar, dan karir).

Layanan Konseling kelompok yang memungkinkan beberapa orang secara bersamasama melangsungkan proses kegiatan menjadikannya lebih efisien dalam hal penggunaan waktu. Hal ini tentu menguntungkan banyak pihak, mulai dari konselor itu sendiri dan konselinya. Manfaat lain dari BK kelompok ini adalah menjadi luasnya perspektif siswa yang mengalami masalah karena mendapatkan banyak masukan dari anggota kelompoknya. Untuk mendapatkan proses yang maksimal dalam pelaksanaan bimbingan konseling kelompok, maka dibutuhkan perencanaan program layanan yang matang. Tidak hanya itu langkah-langkah yang harus ditempuh dalam proses pelaksanaan bimbingan konseling kelompok pun hendaknya telah dipersiapkan dengan matang oleh konselor, bahkan hingga proses tindak lanjut sekali pun. Masalah dalam konseling kelompok biasanya membahas masalah-masalah umum bagi peserta layanan. Jika suasana kelompok belum tercipta maka sulit bagi peserta layanan untuk mengungkapkan masalah pribadinya sehingga konseling kelompok agak sulit pelaksanaannya

Pelayanan konseling kelompok adalah salah satu kegiatan layanan yang paling banyak dipakai karena lebih efektif. Banyak orang yang mendapatkan layanan sekaligus dalam satu waktu. Layanan ini juga sesuai dengan teori belajar karena mengandung aspek social yaitu belajar bersama. Peserta layanan akan berbagi ide dan saling mempengaruhi untuk berkembang menjadi manusia seutuhnya.

Berdasarkan hasil wawancara dan observasi yang dilakukan terhadap instansi calon mitra, diperoleh permasalahan sebagai berikut: 1) Guru BK belum memahami sepenuhnya mengenai pelaksanaan layanan konseling kelompok, 2) Guru BK perlu mendapatkan pelatihan pelaksanaan layanan konseling kelompok dengan tepat. Berbagai permasalahan tersebut sudah jelas akan memberikan dampak yang kurang baik bagi kinerja guru Bimbingan dan Konseling dalam memberikan layanan konseling kelompok.Selama pelaksanaan layanan konseling kelompok, terkadang hanya dilakukan oleh guru BK dengan alakadarnya saja.

Berdasarkan permasalahan tersebut, maka perlu adanya pemberian pelatihan khusus kepada guru BK mengenai pelaksanaan layanan konseling kelompok. Konseling kelompok merupakan layanan bimbingan konseling yang memungkinkan peserta didik (klien) memperoleh kesempatan untuk pembahasan dan pengentasan permasalahan yang dialaminya melalui dinamika kelompok. Prayitno (2004) mengemukakan bahwa layanan konseling kelompok pada dasarnya adalah layanan konseling perorangan yang dilaksanakan didalam suasana kelompok.Dalam pelaksanaan konseling kelompok terdapat konselor dan klien, yaitu para anggota kelompok (yang jumlahnya minimal dua orang).Dalam kegiatan tersebut terjadi hubungan konseling dalam suasana yang hangat, permisif, terbuka dan penuh keakraban.

Selanjutnya Dewa Ketut Sukardi (2003) menjelaskan bahwa konseling kelompok merupakan konseling yang di selenggarakan dalam kelompok, dengan memanfaatkan dinamika kelompok yang terjdi di dalam kelompok itu. Masalah-masalah yang dibahas merupakan masalah perorangan yang muncul di dalam kelompok itu, yang meliputi berbagai masalah dalam segenap bidang bimbingan (bidang bimbingan pribadi, sosial, belajar dan karir). Sementara itu Winkel (2007) mengemukakan bahwa konseling kelompok adalah suatu proses antarpribadi yang dinamis, yang terpusat pada pemikiran dan perilaku yang disadari. Ahli lain, Gazda 1989 (dalam Tatik Romlah, 2001) menyatakan konseling kelompok adalah suatu proses antar pribadi yang dinamis yang memusatkan diri pada pikiran dan perilaku yang sadar dan melibatkan fungsi-fungsi seperti sikap permisif, orientasi pada kenyataan, katarsis, saling pengertian, saling menerima dan membantu.

Selanjutnya, Tatik Romlah (2001) mengemukakan bahwa konseling kelompok adalah upaya untuk membantu individu agar dapat menjalani perkembangannya dengan lebih lancar, upaya itu bersifat pencegahan serta perbaikan agar individu yang bersangkutan dapat menjalani perkembangannya dengan lebih mudah. Berdasarkan uraian-uraian yang disampaikan beberapa ahli di atas maka dapat disimpulkan bahwasannya konseling kelompok merupakan salah satu layanan konseling yang di selenggarakan dalam suasana kelompok yang memanfaatkan dinamika kelompok, serta terdapat hubungan konseling yang hangat, terbuka, permisif dan penuh keakraban.

Meskipun dilaksanaan secara bersamasama dalam kelompok, tujuan utama konseling kelompok tetap mengarah pada tujuan masing- 
masing individu anggota kelompok. Secara umum, tujuan yang dapat diperoleh konseli dalam konseling kelompok adalah :

1. Konseli belajar berkomunikasi dengan seluruh anggota kelompok secara terbuka, dengan saling menghargai dan saling menaruh perhatian, yang akan membawa dampak positif dalam kehidupannya dengan orang lain disekitarnya.

2. Konseli mampu mengembangkan keterampilan berkomunikasi dengan anggota kelompok, khususnya, dan atau dengan orang lain, sehingga dapat saling memberikan bantuan dalam menyelesaikan masalah yang dialaminya, dan menyelesaikan tugas-tugas perkembangan yang khas pada setiap fasefase perkembangannya.

3. Masing-masing konseli mampu menemukan dan memahami dengan lebih baik terhadap dirinya sendiri, sehingga dapat menerima dirinya sendiri dan terbuka terhadap aspekaspek kepribadiannya yang positif.

4. Konseli mampu mengatur dirinya sendiri dan mengarahkan hidupnya sendiri, dimulai dari hubungan antarpribadi di dalam kelompok, dan dilanjutkan dalam kehidupan sehari-hari di dalam lingkungan masyarakat.

5. Konseli menjadi lebih peka terhadap kebutuhan orang lain, dan lebih mampu menghayati dan memahami perasaan orang lain, sehingga membuat konseli lebih sensitif terhadap kebutuhan psikologis dirinya sendiri dan orang lain.

6. Konseli semakin menyadari bahwa hal-hal yang memprihatinkan bagi dirinya kerap menimbulkan rasa prihatin dalam hati orang lain, sehingga konseli tidak akan merasa terisolir lagi dengan masalah yang dihadapi, konseli mendapatkan pemahaman baru bahwa bukan hanya dirinyalah yang mengalami masalah tersebut.

7. Konseli lebih menyadari dan menghayati makna dari kehidupan bersama yang mengandung tuntutan menerima orang lain dan harapan akan diterima orang lain.

8. Konseli dapat menetapkan suatu sasaran atau target yang ingin dicapai, yang diwujudkan dalam sikap dan perilaku yang lebih konstruktif.

Secara khusus, tujuan konseling kelompok adalah membantu konseli agar menjadi lebih terbuka dan jujur terhadap dirinya sendiri dan orang lain, belajar mempercayai diri sendiri dan orang lain, berkembang untuk lebih menerima diri sendiri, belajar berkomunikasi dengan orang lain, belajar untuk lebih akrab dengan orang lain, belajar untuk bergaul dengan sesama dan atau lawan jenis, belajar memberi dan menerima, menjadi peka terhadap perasaan dan kebutuhan orang lain, dan meningkatkan kesadaran diri sehingga akan merasa lebih bebas dan tegas dalam memilih.

Konseling kelompok bersifat memberikan kemudahan dalam pertumbuhan dan perkembangan individu, dalam artian konseling kelompok memberikan dorongan dan motivasi kepada individu untuk membuat perubahan-perubahan dengan memanfaatkan potensi secara maksimal sehingga dapat mengaktualisasikan dirinya. Dengan penguatan dari kelompok, konseli bisa terdorong untuk melakukan eksplorasi potensi diri maupun kelemahannya. Konseling kelompok dapat menyediakan rasa aman yang dibutuhkan anggota kelompok untuk secara spontan dan bebas berinteraksi dan mengambil resiko sehingga meningkatkan kemungkinan mereka untuk saling berbagi pengalaman dengan orang lain yang memiliki pengalaman serupa.

$$
\text { Konseling kelompok dapat }
$$
memberikan individu berbagai macam pengalaman kelompok yang membantu mereka belajar berfungsi secara efektif, mengembangkan toleransi terhadap stress dan kecemasan, dan menemukan kepuasan bersama dalam bekerja dan hidup bersama orang lain. Melalui kelompok, dengan kontak kelompok membawa individu pada kesadaran diri bahwa ada cara pandang yang berbeda dengan dirinya mengenai dirinya sendiri, dan reaksi kelompok dapat membawa seseorang mempertimbangkan persepsi lain dari dirinya. Ini terjadi dengan kesadaran yang tulus, yang difasilitasi oleh interaksi kelompok. Melalui interaksi dengan anggota kelompok, individu juga akan mengembangkan berbagai keterampilan yang pada intinya meningkatkan kepercayaan diri, kepercayaan terhadap orang lain, dan bagaimana berfikir positif terhadap orang dan persoalanpersoalan yang dihadapinya.

Tujuan pengabdian ini untuk, 1) Meningkatnya pemahaman guru BK mengenai pelaksanaan layanan konseling kelompok, 2) Meningkatnya kemampuan guru BK dalam memberikan layanan konseling kelompok bagi siswa. Manfaat yang dapat diperoleh dari pengabdian ini yaitu : 1) Guru BK dapat memahami prosedur pelaksanaan layanan 
konseling kelompok dengan baik, 2) Guru BK dapat mengaplikasikan pelaksanaan layanan konseling kelompok kepada siswa secara tepat, 3) Pelaksanaan Konseling Kelompok dapat berjalan sesuai dengan kaidah dan aturan pelaksanaan yang benar.

\section{METODE}

Kegiatan pengabdian dilaksanakan melalui pelatihan dan pendampingan berupa Pelaksanaan Konseling Kelompok Pada Guru BK SMA/MA Kabupaten Bantu. Pelatihan ini akan dilaksanakan sebanyak 2 kali. Kegiatan pengabdian direncanakan akan dilaksanakan pada bulan Februari2017.Kegiatan pengabdian dilakasanakan melalui beberapa metode pelatihan, yaitu:

Metode ceramah merupakan metode yang tepat digunakan untuk teknik pemberian informasi dalam layanan bimbingan dan konseling. Metode ceramah dipilih untuk memberikan penjelasan konsep dasar konseling kelompok. Dalam metode ceramah ini juga dijelaskan mengenai tujuan, manfaat dan langkah-langkah konseling kelompok. Kemampuan guru BK dalam melaksanakan konseling kelompok dengan baik akan sangat berpengaruh terhadap persepsi siswa mengenai kualitas dari seorang guru BK. Sehingga guru BK dituntut untuk mampu memberikan layanan tersebut dengan baik.

Metodetanya jawab adalah metode pemberian layanan yang memungkinkan terjadinya komunikasi langsung yang bersifat two ways traffic sebab pada saat yang sama terjadi dialog antara pemberi materi dengan peserta pelatihan. Peserta bertanya, pemateri menjawab atau pemateri bertanya, peserta menjawab. Dalam komunikasi ini terlihat adanya hubungan timbal balik secara langsung antara pemateri dengan peserta. Metode tanya jawab ini bertujuan untuk: (1) Untuk mengetahui sampai sejauh mana materi konseling kelompok dikuasai oleh peserta pengabdian. (2) Untuk merangsang peserta pengabdian berpikir dan mempraktekkan pengetahuan tentang konseling kelompok. (3) Memberi kesempatan pada peserta untuk mengajukan permasalahan tentang konseling kelompokyang belum dipahami.

Metode praktikum merupakan salah satu metode yang efektif untuk memperjelas pemahaman. Dalam pelatihan ini selain dibekali dengan pengenalan tentang tahapan pelaksanaan konseling kelompok yang benar. Selain itu, peserta juga langsung diajak untuk mempraktekkan layanan konseling kelompok dengan model yang sederhana. Melalui pemberian contoh dari instruktur, peserta pelatihan mencoba langsung mempraktikkan pelaksanaan layanan konseling kelompok. Peserta pelatihan dilatih kemampuan dan keterampilannya dalam melakukan konseling kelompok dengan baik dan benar, sehingga dampaknya yaitu para peserta semakin paham dan terampil dalam memberikan layanan konseling kelompok kepada siswa.

\section{HASIL DAN PEMBAHASAN}

Kegiatan pengabdian kepada masyarakat ini dilaksanakan pada hari Jumat dan Sabtu, tanggal 2-3 Februari 2018. Adapun susunan acara pengabdian Sosialisasi Pelaksanaan Konseling Kelompok Pada Guru BK SMA/MA Kabupaten Bantul dilaksanakan diawali dengan registrasi, penyampaian materi mengenai konsep Layanan Konseling kelompok dan Unsur-unsur konseling kelompok kemudian tanya jawab. Dihari kedua dilaksanakan Penyampaian materi tentang Dinamika kelompok dan tahapan-tahapan pelaksanaan konseling kelompok refleksi dan tanya jawab

Pengabdian ini dilaksanakan di MGBK SMA-MA Kabupaten Bantul. Kegiatan pengabdian di MGBK SMA-MA Kabupaten Bantul dilakukan selama 2 hari. Pada hari pertama kegiatan pengabdian dilakukan dengan memberikan materi tentang konsep Layanan Konseling kelompok dan Unsur-unsur konseling kelompok. Sedangkan hari kedua pengabdian dilakukan dengan memberikan materi tentang Dinamika kelompok dan tahapan-tahapan pelaksanaan konseling kelompok. Pengabdian kepada masyarakat ini diikuti oleh 40 peserta dari anggota MGBK SMA-MA Kabupaten Bantul. Pengabdian pada masyarakat dilakukan selama 2 hari dan masing-masing hari dilakukan selama 2 jam diawali pada pukul 10.00 WIB dan diakhiri pada pukul 12.00 WIB.

Pada saat pemberian materi oleh pemateri pengabdian, para peserta sangat antusias mendengarkan instruksi pemateri. Antusias peserta pengabdian ditunjukkan dengan munculnya berbagai macam pertanyaan yang berkaitan dengan materi yang disampaikan. Sesi tanya jawab benar-benar dimanfaatkan oleh peserta guna mendapatkan pemahaman yang diinginkan. Peserta pelatihan terlihat sangat senang adanya pelatihan peningkatan profesionalisme guru BK ini. Hal 
tersebut dikarenakan pelatihan-pelatihan semacam ini sangat jarang diperoleh guru BK sedangkan kecakapan guru BK dalam memberikan layanan konseling kelompok sangat dituntut oleh pemerintah demi tercapainya pelaksanaan layanan Bimbingan dan Konseling yang baik.
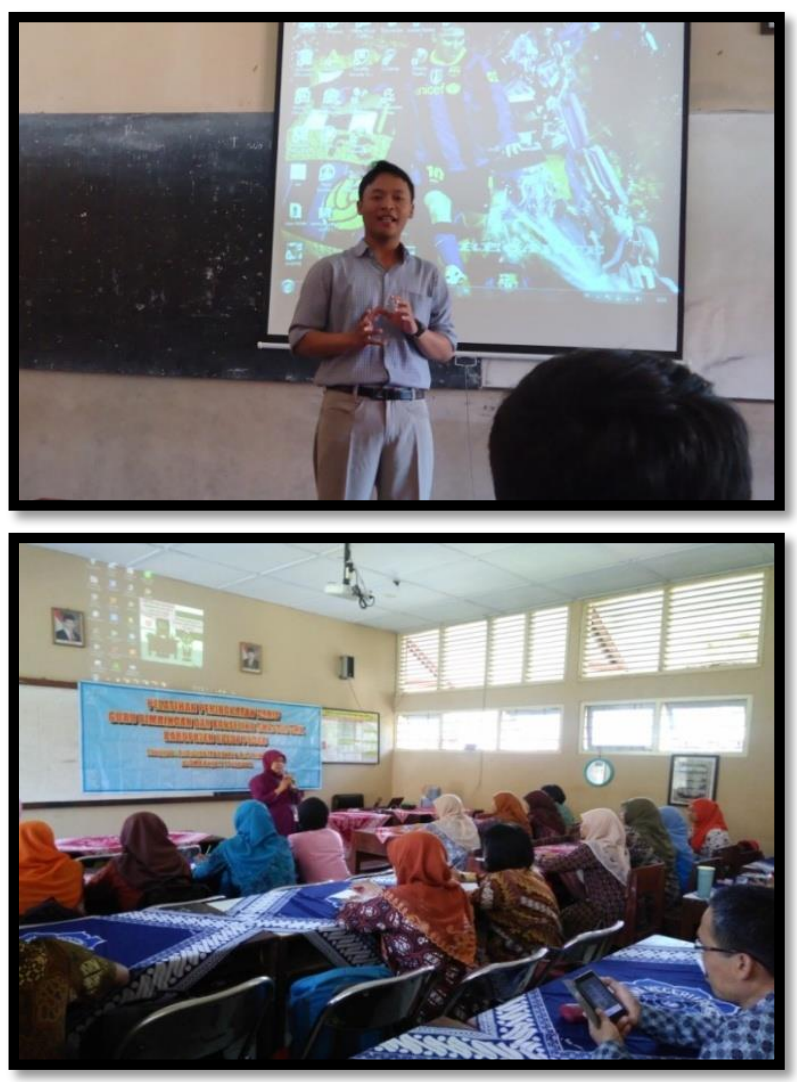

Hasil dan luaran dari pelaksanaan pengabdian kepada masayarakat dapat dilihat dari tabel berikut :

Tabel 1. Luaran Pengabdian

\begin{tabular}{lllr}
\hline No & Jenis Luaran & Indikator Capaian \\
& & & \\
1 & Publikasi Ilmiah & Submitted. & \\
& di MATAPPA : & Menyatakan & bahwa \\
& Jurnal Pengabdian & pengabdi r relah \\
& Kepada & melakukan rubmit \\
& Masyarakat & pada lembaga jurnal \\
& & dengan menunjukkan \\
& & bukti submit.
\end{tabular}

2 Peningkatan Ada (terlihat dari kualitas dan antusias pertanyaan kuantitas produk dan praktek dari guru BK SMA-MA Kabupaten Bantul)

3 Peningkatan Ada (Guru memahami

\begin{tabular}{|c|c|c|}
\hline & $\begin{array}{l}\text { pemahaman dan } \\
\text { keterampilan } \\
\text { masyarakat }\end{array}$ & $\begin{array}{l}\text { bagaimana cara } \\
\text { melaksanakan layanan } \\
\text { konseling kelompok } \\
\text { dengan baik) }\end{array}$ \\
\hline 4 & $\begin{array}{l}\text { Peningkatan } \\
\text { kesejahteraan } \\
\text { masyarakat/Guru }\end{array}$ & $\begin{array}{lr}\text { Ada } & \text { (Guru } \\
\text { mendapatkan solusi } \\
\text { yaitu berupa cara } \\
\text { melaksanakan } \\
\text { konseling kelompok } \\
\text { yang benar) }\end{array}$ \\
\hline 5 & Buku ajar/modul & $\begin{array}{l}\text { Ada (berupa print out } \\
\text { powerpoint) }\end{array}$ \\
\hline
\end{tabular}

\section{SIMPULAN DAN SARAN}

Adapun kesimpulan dalam pengabdian kepada masyarakat di MGBK SMA-MA Kabupaten Bantul yaitu Guru BK SMA-MA Kabupaten Bantul mampu memahami akan pentingnya layanan konseling kelompok sebagai salah satu layanan Bimbingan dan Konseling. Adapun saran yang diberikan untuk Guru BK SMA,MA dan SMK di Kabupaten Bantul yaitu Guru BK SMA-MA Kabupaten Bantul hendaknya melakukan peningkatan kemampuan memberikan layanan konseling kelompok dengan cara rajin berlatih dan menerapkan kemampuan yang dimiliki kepada siswa. Selain itu, Guru BK SMA-MA Kabupaten Bantul lebih intensif lagi dalam menjalankan tugasnya sebagai Guru pembimbing dengan menjalankan layanan BK khusus nya layanan konseling kelompok.

\section{DAFTAR RUJUKAN}

Sukardi,D,K. (2003). Dasar-dasar Bimbingan dan Penyuluhan di Sekolah. Surabaya: Usaha Nasional.

Gladding, S. T. (2012). Konseling: Profesi yang Menyeluruh (Edisi Keenam). Jakarta: Permata Puri Media.

Natawidjaja, R. (2009). Konseling Kelompok: Konsep Dasar dan Pendekatan. Bandung : Rizqi.

Nurihsan, A. J. (2013). Bimbingan dan Konseling Dalam Berbagai Latar Kehidupan. Bandung: Refika Aditama.

Prayitno dan Erman Amti. (2009). Dasar-dasar Bimbingan dan Konseling.Jakarta: Rineka Cipta. 
Vol 1 No 1, Maret 2018

Prayitno. (1995). Layanan Bimbingan Dan Konseling Kelompok Dasar Dan Profil. Jakarta: Rineka Cipta.

Prayitno. (2004). Layanan Bimbingan Kelompok Dan Konseling Kelompok. Padang: Universitas Negeri Padang.
Romlah, T. (2001). Teori dan Praktek Bimbingan Kelompok. Malang: Universitas Negeri Malang. 